\title{
LABORATÓRIO CASA SUSTENTÁVEL: ARQUITETURA BIOCLIMÁTICA QUE PROMOVE ORIENTAÇÃO AMBIENTAL
}

\section{ARTIGO ORIGINAL}

ALMEIDA, Karla Carvalho de ${ }^{1}$, SOUZA, Rosiane de Oliveira ${ }^{2}$, COSTA, Naiara Vilela ${ }^{3}$

ALMEIDA, Karla Carvalho de. SOUZA, Rosiane de Oliveira. COSTA, Naiara Vilela. Laboratório Casa Sustentável: arquitetura bioclimática que promove orientação ambiental. Revista Científica Multidisciplinar Núcleo do Conhecimento. Ano. 07, Ed. 01, Vol. 02, pp. 27-52. Janeiro de 2022. ISSN: 2448-0959, Link de acesso: https://www.nucleodoconhecimento.com.br/arquitetura/arquiteturabioclimatica, DOI: 10.32749/nucleodoconhecimento.com.br/arquitetura/arquiteturabioclimatica

\section{RESUMO}

O Laboratório Casa Sustentável (LCS) consiste em um projeto de ensino, pesquisa e extensão da Faculdade de Arquitetura e Urbanismo (FAU) da Universidade Federal de Juiz de Fora (UFJF), em que são aplicadas técnicas arquitetônicas de bioclimatismo, de sustentabilidade e de conforto ambiental. O espaço resultante faz referência aos ambientes residenciais comumente encontrados em moradias brasileiras, expondo as soluções adotadas e os seus desempenhos - observados na prática - em relação aos confortos térmico, acústico e lumínico. Ao longo do trabalho, buscou-se responder à seguinte pergunta: de que forma o Laboratório Casa Sustentável atua a fim de estabelecer diálogo e orientação ambiental às comunidades local e acadêmica? O objetivo é apresentar o projeto da Casa, a

\footnotetext{
${ }^{1}$ Pós-graduação em Arquitetura da Paisagem pela Pontifícia Universidade Católica de Minas Gerais (PUCMinas) e graduação em Arquitetura e Urbanismo pela Universidade Federal de Juiz de Fora (UFJF). ORCID: 0000-0003-2425-4382.

${ }^{2}$ Graduação em Arquitetura e Urbanismo pela Universidade Federal de Juiz de Fora (UFJF). ORCID: 0000-00015760-8189.

${ }^{3}$ Graduação em Arquitetura e Urbanismo pela Universidade Federal de Juiz de Fora (UFJF). ORCID: 0000-00018382-7780.
}

RC: 104796

Disponível em: https://www.nucleodoconhecimento.com.br/arquitetura/arquiteturabioclimatica 
metodologia utilizada para o seu desenvolvimento, e o seu funcionamento atual através de um trajeto guiado - como forma de ensino, pesquisa, extensão e diálogo com a comunidade. Como metodologia, houve a análise do referencial teórico desde o início do projeto - entre estudos de caso, livros, normas sobre arquitetura bioclimática, entre outros -, posteriormente houve o trajeto walkthrough que demonstra, através de fotografias e desenhos esquemáticos, as técnicas de conforto ambiental utilizadas em cada ambiente. Além dessas estratégias, acrescentam-se as informações coletadas através da experiência como projetistas e guias de visitação pelas autoras. Como resultado da pesquisa, tem-se a demonstração, na prática, do papel de educação ambiental que o Laboratório faz, tanto em relação à comunidade acadêmica, quanto em relação à população em geral. Além disso, tem-se a exposição das técnicas de bioclimatismo empregadas, a fim de democratizar e possibilitar a reprodução desse conhecimento.

Palavras-chave: Arquitetura bioclimática, Sustentabilidade, Conforto ambiental.

\section{INTRODUÇÃO}

O Laboratório Casa Sustentável (LCS) está localizado no Jardim Botânico da cidade de Juiz de Fora, Minas Gerais, e é produto do projeto de ensino, pesquisa e extensão do Laboratório de Conforto Ambiental (ECOS) da Faculdade de Arquitetura e Urbanismo da Universidade Federal de Juiz de Fora (UFJF), em que são aplicadas técnicas arquitetônicas de sustentabilidade e bioclimatismo.

Sua finalidade é, além de promover diálogo com a comunidade local - transmitindo informação à população, e possibilitando que os visitantes possam replicar as técnicas presentes na Casa em suas próprias moradias -, promover também o ensino ambiental prático, recebendo grupos escolares e acadêmicos para realizar a visita guiada pelos monitores.

O presente artigo, tem como questão norteadora: de que forma o Laboratório Casa Sustentável atua a fim de estabelecer diálogo e orientação ambiental às 
comunidades local e acadêmica? Seu objetivo é registrar e expor a metodologia projetual, as técnicas utilizadas e o resultado prático atual - através de um trajeto guiado pela Casa - para que, desta forma, projetos como este possam ser reproduzidos, democratizando o conhecimento sobre sustentabilidade residencial.

\section{REFERENCIAL TEÓRICO}

A pesquisa teve como embasamento os registros produzidos anteriormente pelos participantes do projeto durante os estudos de caso que inspiraram a Casa (ZAMBRANO et al., 2008).

Posteriormente, foram analisadas as normas projetuais que embasaram o projeto: como as estratégias de arquitetura bioclimática (ABNT, 2004); de seleção de materiais e de técnicas construtivas baseadas em princípios de sustentabilidade (HALLYDAY, 2008; SANMIGUEL, 2007); e de conceitos de Sistemas prediais ecoeficientes (SCHLEIFER, 2010); que serão explicados ao longo do trabalho.

Além disso, foram coletadas informações através de visitas in loco na sede do LCS, e da prática de trabalho de bolsistas vinculados ao projeto.

\section{METODOLOGIA}

A metodologia de trabalho foi definida por estratégias práticas e teóricas. Inicialmente, houve o estudo dos arquivos do projeto que serão explicitados nas seções seguintes (plantas, pranchas, desenhos esquemáticos, fotografias e vídeos explicativos) e dos artigos citados anteriormente (produzidos ainda em fase de estudos de caso e embasamento teórico).

Posteriormente, foram feitas visitas guiadas em forma de walkthrough pelas pesquisadoras do presente artigo, registrando fotografias que demonstram o trajeto. Walkthrough, por sua vez, consiste em uma ferramenta de avaliação pós-ocupação, em que o trajeto é registrado através de fotografias, desenhos e esquemas visuais 
descritivos dos aspectos positivos e negativos do local, de forma que sejam registrados detalhes pré-estabelecidos (RHEINGANTZ et al., 2009).

Aliado a isso, houve o acréscimo de informações pelas autoras, adquiridas ao longo da experiência como bolsistas do projeto. Como resultado, tem-se a comparação entre o embasamento teórico utilizado para a construção da Casa Sustentável e a sua implantação na prática, bem como seu impacto no meio acadêmico e na comunidade local como equipamento promotor de educação ambiental.

\section{HISTÓRIA DA CASA SUSTENTÁVEL}

O Laboratório teve início em 2012, quando a UFJF adquiriu a Fazenda da Tapera, que estava sendo oferecida pelos seus proprietários para o mercado imobiliário (ZAMBRANO, 2020).

Assim, a Universidade desenvolveu um plano diretor que o definia como Jardim Botânico, com objetivo de oferecer visitação à população, e disponibilizar o espaço de ensino, pesquisa e extensão aos seus discentes e docentes (ZAMBRANO, 2020).

Ainda no mesmo ano, a equipe responsável pelo projeto convidou o Laboratório de Conforto Ambiental (ECOS), da Faculdade de Arquitetura e Urbanismo/UFJF, para desenvolver o que denominaram como Casa Ecológica, que estava prevista no Plano Diretor do Jardim (ZAMBRANO, 2020). 
Figura 01: Primeira visita da equipe responsável pela Casa Sustentável ao Jardim Botânico de Juiz de Fora.

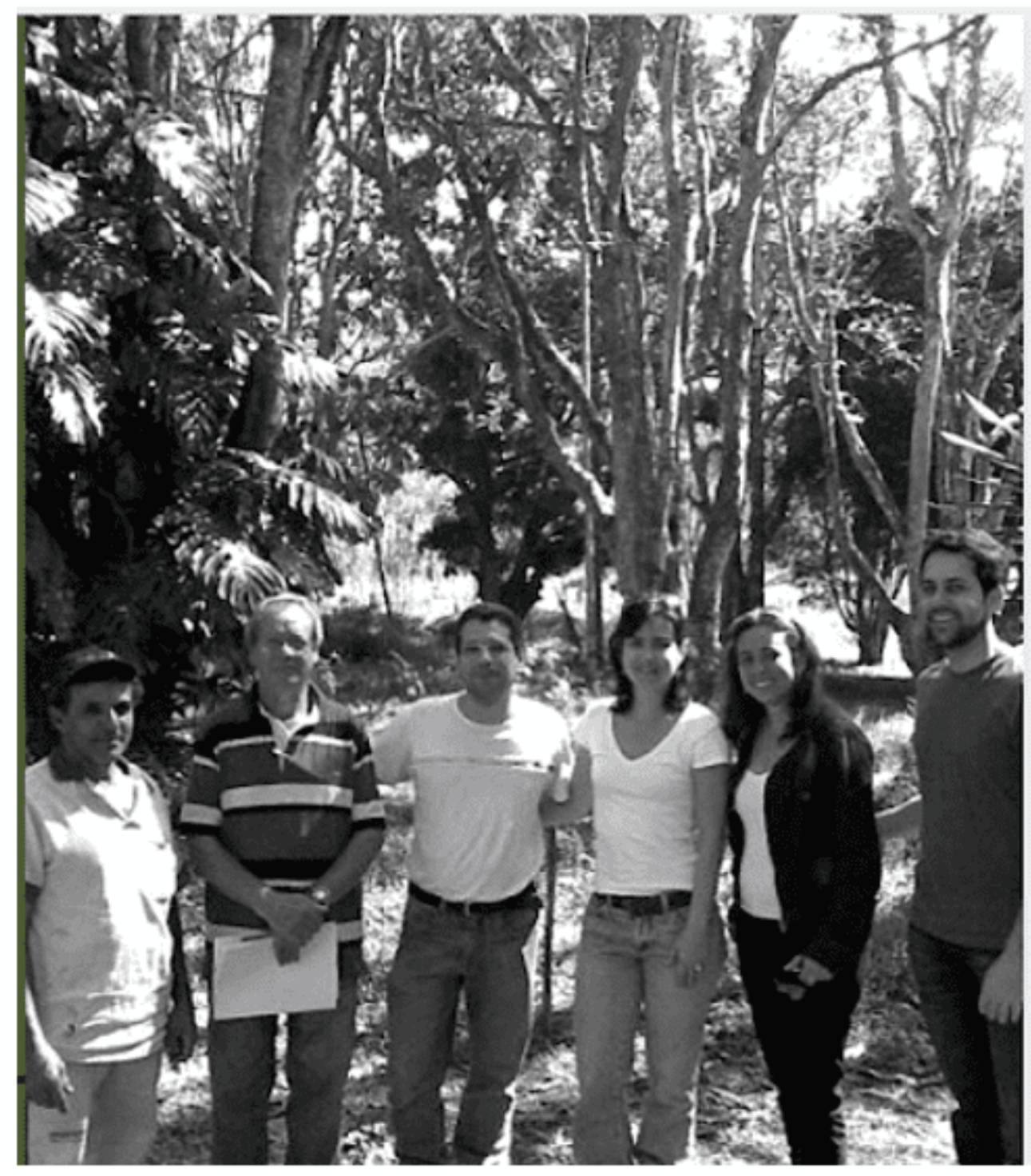

Fonte: ZAMBRANO, 2012.

\section{METODOLOGIA PROJETUAL DA CASA SUSTENTÁVEL}

Como metodologia de projeto, foram definidas 5 etapas. A primeira consistiu na pesquisa de referências de casos de universidades que desenvolveram casas com o perfil voltado para a sustentabilidade e/ou ecologia, abrangendo diversos fins, como pesquisa, simulação de determinadas tecnologias, contato com a comunidade, entre

RC: 104796

Disponível em: https://www.nucleodoconhecimento.com.br/arquitetura/arquiteturabioclimatica 
outros. Entre os exemplos mapeados, destacam-se a Casa Ecológica e a Casa Solar Eficiente da Universidade Federal do Rio de Janeiro (UFRJ), a Casa Inteligente da Universidade Estadual do Oeste do Paraná (Unioeste), e a Casa Eficiente da Universidade Federal de Santa Catarina/UFSC (ZAMBRANO et al., 2008).

A segunda etapa tratou da definição de objetivos para o projeto, que consistiram na associação entre os princípios dos pilares da sustentabilidade - ambiental, social e econômico-; na relação entre pesquisa, ensino e extensão; em criar um espaço de visitação, interação e exposição de soluções técnicas e arquitetônicas para sensibilizar a população em relação à sustentabilidade, utilizando parâmetros acessíveis e reprodutíveis; e utilizar o retorno de opiniões durante a visitação para nutrir as pesquisas de conforto ambiental e de ensino (ZAMBRANO et al., 2008).

A terceira etapa definiu a formação da equipe de projeto, que contou com diversos grupos de pesquisa da UFJF, como o GEES (Grupo de Estudos em Edificação Sustentável), PET Elétrica (Programa de Educação Tutorial), Pesquisa Aplicada em Materiais e Construção Sustentável, Prolnfra (Programa de Infraestrutura e Gestão), GET Computação (Grupo de Educação Tutorial), NIMO (Núcleo de Iluminação Moderna), Coordenação do Curso de Ciências Biológicas da UFJF, e grupo de Design de Móveis do Instituto Federal de Educação, Ciência e Tecnologia/IFET (ZAMBRANO et al., 2008).

A quinta etapa aborda o projeto propriamente dito, em que, primeiramente, foram analisadas as características climáticas da área: localiza-se na região Sudeste do Brasil; na mesorregião Zona da Mata (IBGE, 2010); microrregião Juiz de Fora (IBGE, 2010); possui clima Tropical de Altitude (STRAHLER, s/d); em altitude de 800 metros, que proporciona temperaturas mais amenas; possui temperatura média anual de $18^{\circ}$ a $24^{\circ}$ (ESTAÇÃO CLIMATOLÓGICA PRINCIPAL, 2021); umidade relativa de 70\% A 90\% (PROJETEEE, 2021), que torna-se um agravante durante $\circ$ frio; e ventos predominantes na direção Norte-Sul, na Zona Bioclimática Z3 (ABNT, 2004). Apesar da proximidade com a cidade do Rio de Janeiro, por exemplo, essas 
características aproximam o clima da cidade ao de Florianópolis e Santa Catarina (ZAMBRANO et al., 2008).

\section{ESTRATÉGIAS PROJETUAIS E EXECUÇÃO DA CASA SUSTENTÁVEL}

Como estratégia, então, para os meses frios, foram desenvolvidos o aquecimento solar passivo e a inércia térmica nas paredes internas para ajudar a reter calor. Segundo a norma do zoneamento climático, as paredes externas podem ser leves e refletoras para que, no verão e no inverno, a edificação apresente o comportamento adequado (ABNT, 2004). Durante os meses quentes, trabalhou-se valorizando a ventilação para refrescar e remover o excesso de umidade do interior da edificação (ZAMBRANO, 2020).

Quanto à implantação da edificação no terreno, foi escolhido um local que já estava descampado e é localizado em uma região periférica do Jardim Botânico com o objetivo de não ofuscar o protagonismo do paisagismo nativo e exuberante no restante do Jardim (ZAMBRANO, 2020).

Figura 02: Foto aérea da Casa Sustentável.

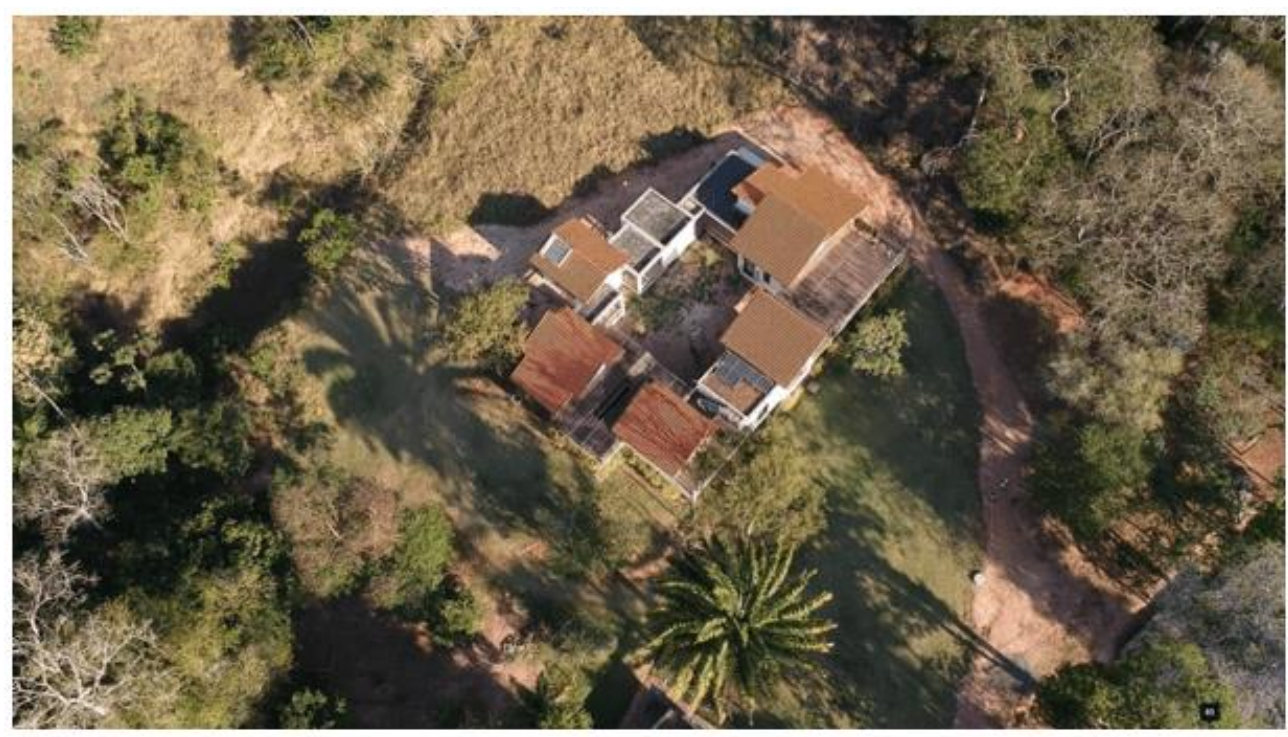

Fonte: Acervo do Laboratório Casa Sustentável (LCS), 2019.

RC: 104796

Disponível em: https://www.nucleodoconhecimento.com.br/arquitetura/arquiteturabioclimatica 
Procurando minimizar o impacto ambiental da construção, a casa foi implantada de forma elevada em relação ao nível do solo, através de pilares de sustentação, preservando a topografia em sua forma original (ZAMBRANO, 2020).

Figura 03: Elevação da Casa e preservação da topografia natural.

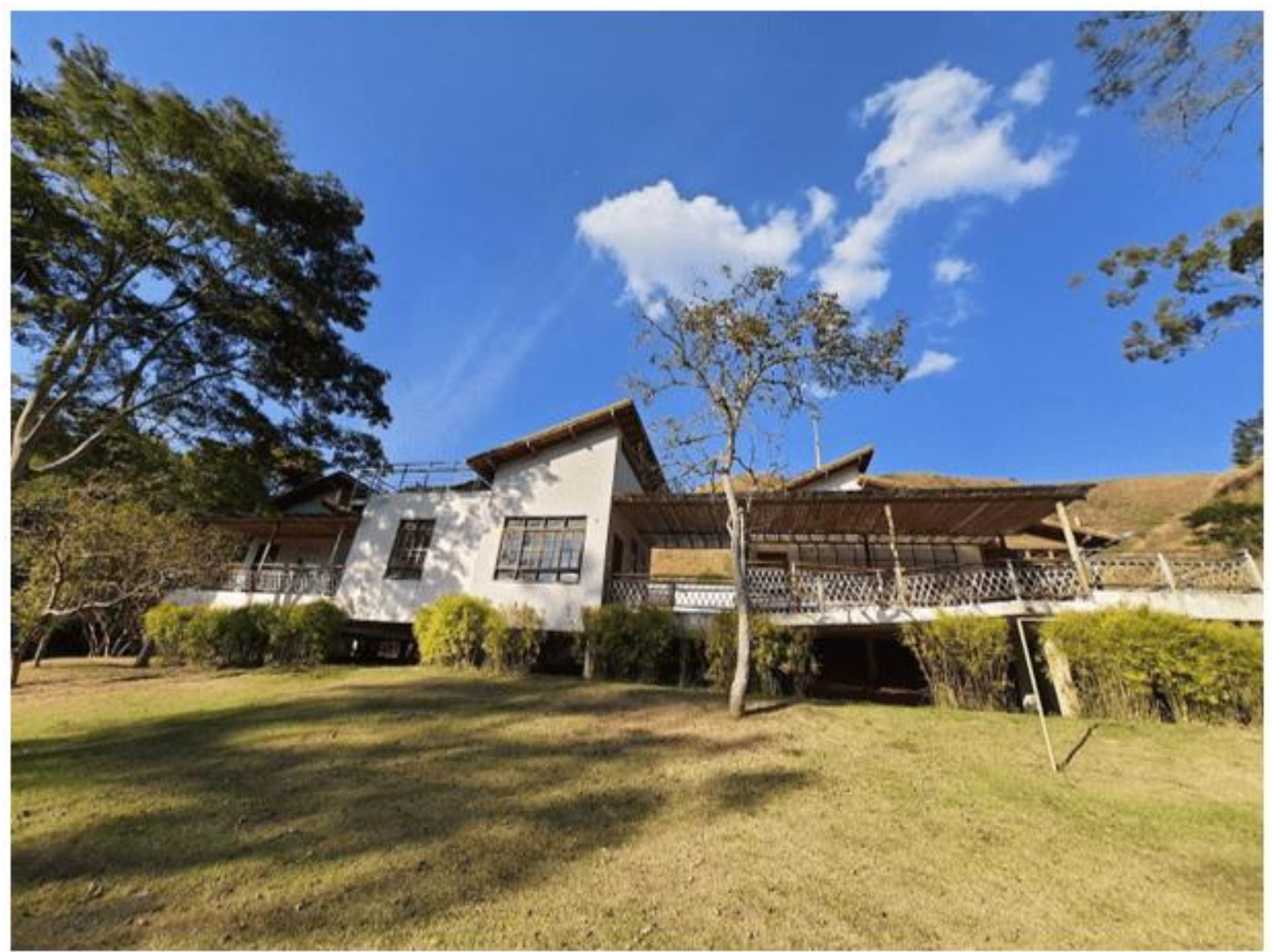

Fonte: Acervo do Laboratório Casa Sustentável (LCS), 2019.

Apesar de aparentar possuir grande volume construído, a casa mantém o jardim central como área permeável e natural, preservando o diálogo com o entorno.

RC: 104796

Disponível em: https://www.nucleodoconhecimento.com.br/arquitetura/arquiteturabioclimatica 
Figura 04: Jabuticabeira no pátio interno.

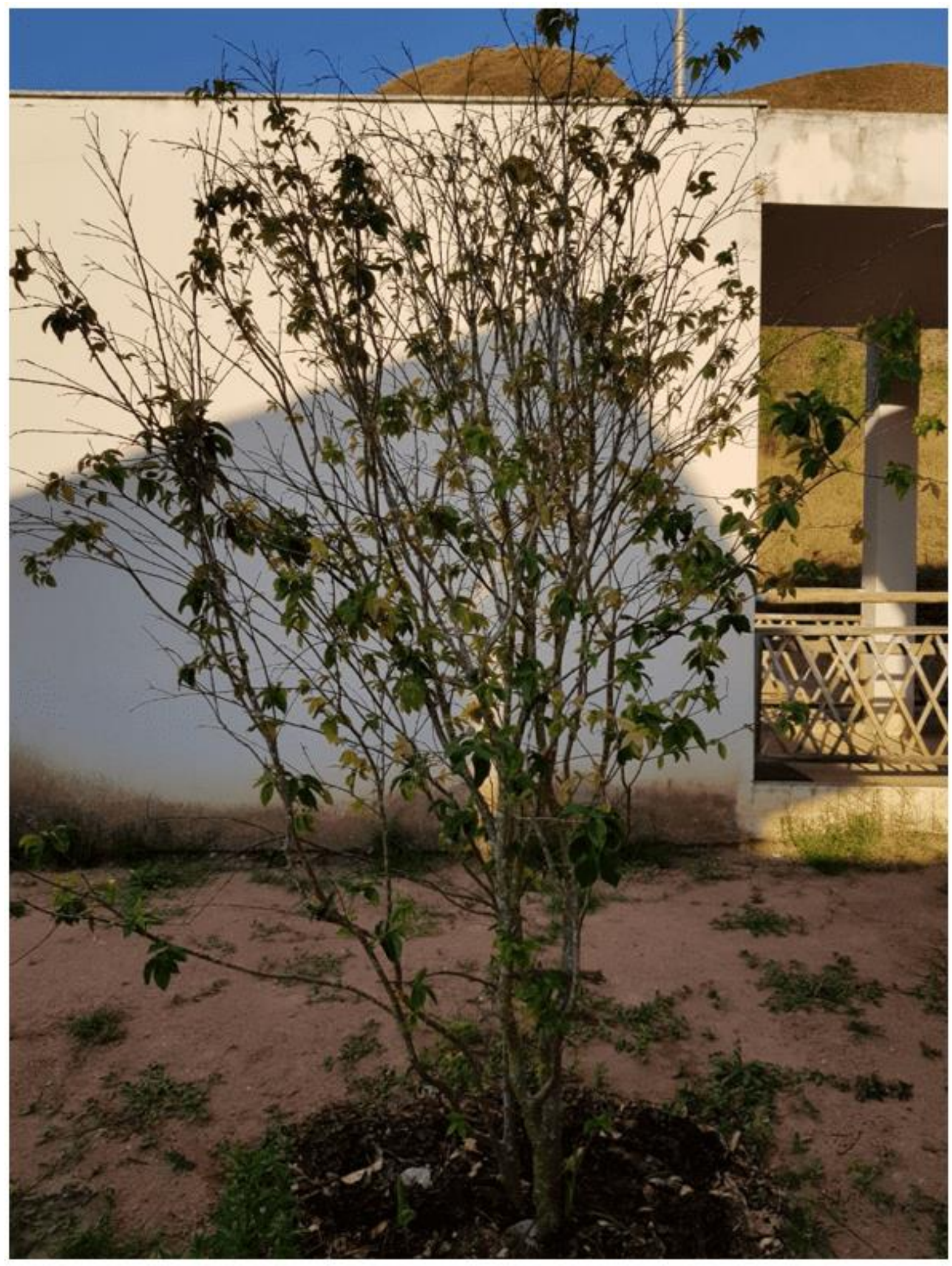

Fonte: Acervo do Laboratório Casa Sustentável (LCS), 2018.

RC: 104796

Disponível em: https://www.nucleodoconhecimento.com.br/arquitetura/arquiteturabioclimatica 
A implantação parte, também, do eixo Norte-Sul, levando em consideração o vento predominante em Juiz de Fora e a trajetória solar, para que a iluminação e a ventilação naturais provoquem o resultado desejado quanto ao conforto ambiental (ZAMBRANO, 2020).

Figura 05: Setorização da Casa Sustentável.

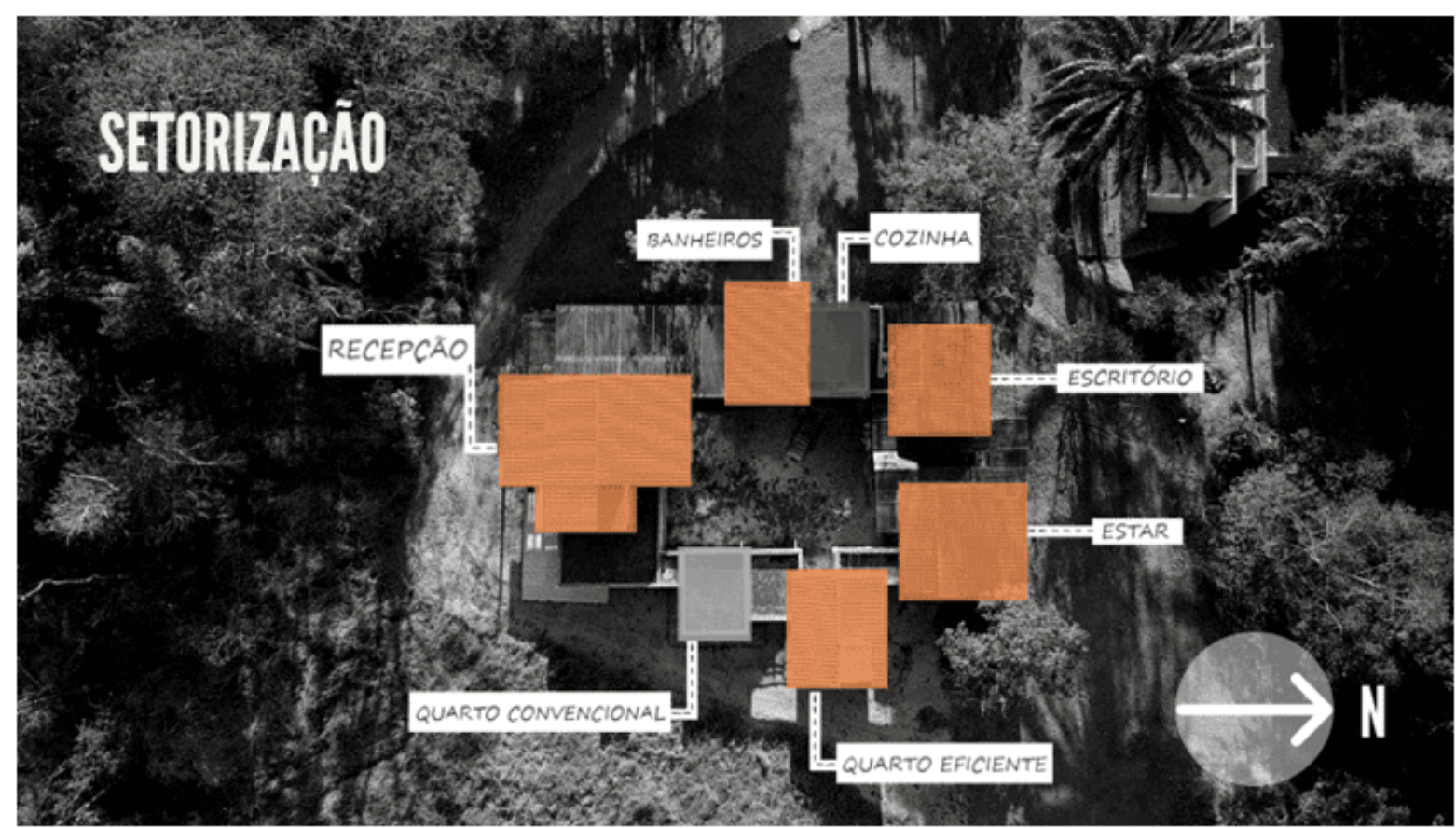

Fonte: Acervo do Laboratório Casa Sustentável (LCS), 2020. Modificada pelas autoras, 2020.

Dentro da casa, encontram-se sete cômodos distanciados entre si por uma passarela, para que a estratégia aplicada em um destes seja estudada sem sofrer nenhum tipo de influência do outro ambiente. Cada cômodo terá suas estratégias explicadas a seguir, seguindo a ordem do trajeto da visita guiada.

\section{WALKTHROUGH: O TRAJETO DE VISITAÇÃO}

A visitação se dá por um percurso circular iniciado pela recepção, seguida pelo quarto convencional, posteriormente pelo quarto eficiente, escritório, sala de estar, áreas molhadas (cozinha e banheiro) e é finalizado novamente pela recepção.

RC: 104796

Disponível em: https://www.nucleodoconhecimento.com.br/arquitetura/arquiteturabioclimatica 
A recepção apresenta como estratégias a ventilação cruzada e o efeito chaminé, onde as janelas superiores, opostas entre si no eixo norte-sul, possibilitam a retirada do ar quente e renovação com ar fresco.

Figura 06: Abertura superior na recepção.

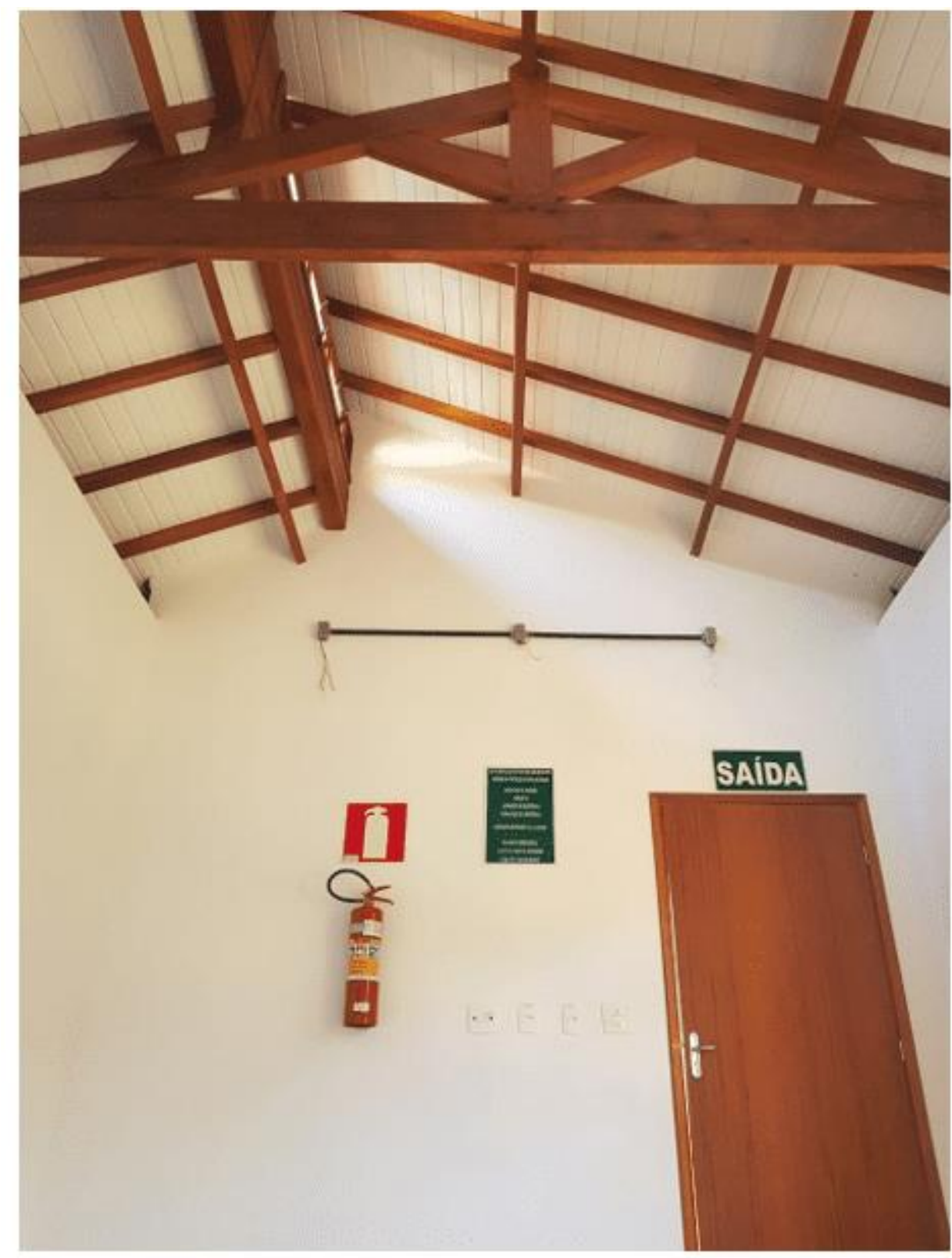

Fonte: Acervo do Laboratório Casa Sustentável (LCS), 2019.

RC: 104796

Disponível em: https://www.nucleodoconhecimento.com.br/arquitetura/arquiteturabioclimatica 
A parede trombe, ainda na recepção, consiste em uma parede de pedra com vidro externo e veneziana, possibilitando a entrada de ar fresco (não permitindo a incidência solar no vidro em dias quentes) ou de ar quente (permitindo a incidência solar em dias frios), a depender da necessidade da época do ano.

Figura 07: Parede Trombe e placa solar fotovoltaica na recepção.

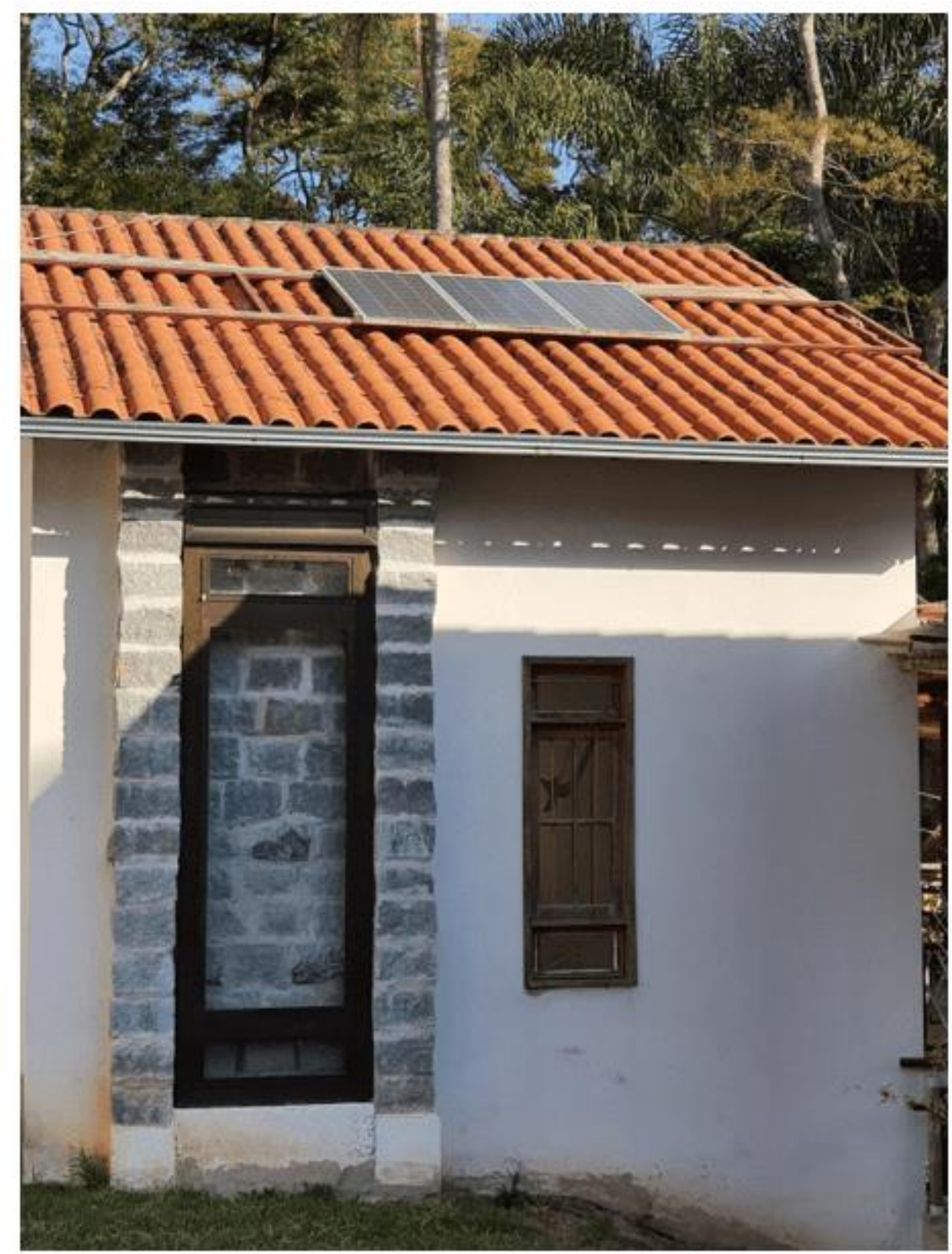

Fonte: Acervo do Laboratório Casa Sustentável (LCS), 2019.

RC: 104796

Disponível em: https://www.nucleodoconhecimento.com.br/arquitetura/arquiteturabioclimatica 
Ainda na recepção, há a parede verde em fase de pré-execução, estrategicamente posicionada na fachada que recebe maior incidência solar durante a tarde - como mostra a imagem seguinte da sua fase projetual.

Figura 08: Parede verde.

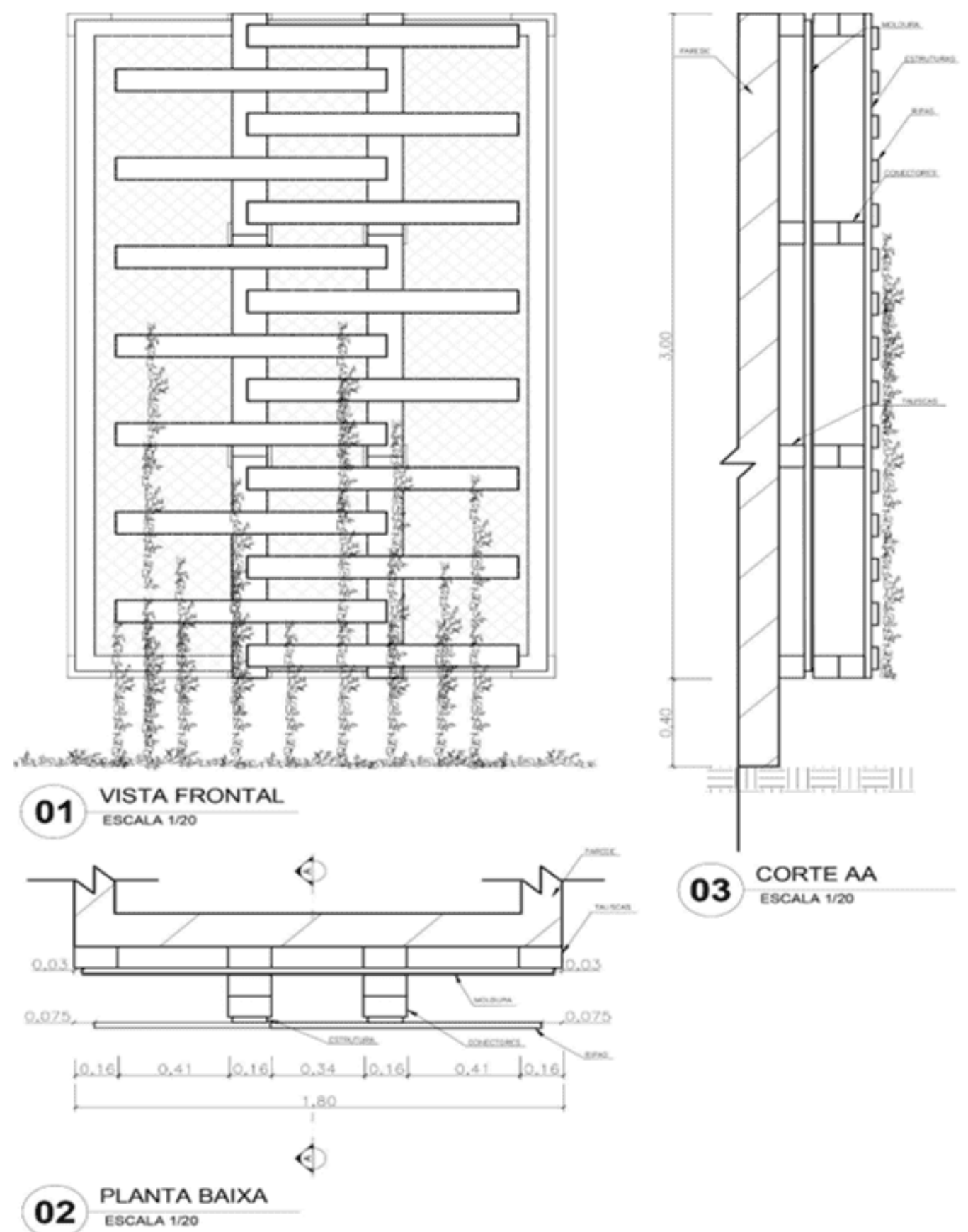

Fonte: Acervo do Laboratório Casa Sustentável (LCS), 2018.

RC: 104796

Disponível em: https://www.nucleodoconhecimento.com.br/arquitetura/arquiteturabioclimatica 
Além disso, há o uso da iluminação natural, que minimiza a necessidade de lâmpadas acesas durante o dia e gera energia com o uso das placas solares fotovoltaicas.

Em seguida, o quarto convencional apresenta-se sem estratégias bioclimáticas e é semelhante ao ambiente comumente encontrado na cidade pela população, para que seja comparado ao quarto eficiente.

O piso refletor e o posicionamento da janela para Sul proporcionam, respectivamente, reverberação de eco (prejudicando o conforto acústico) e sensação de frio e umidade no local.

Figura 09: Quarto Convencional.

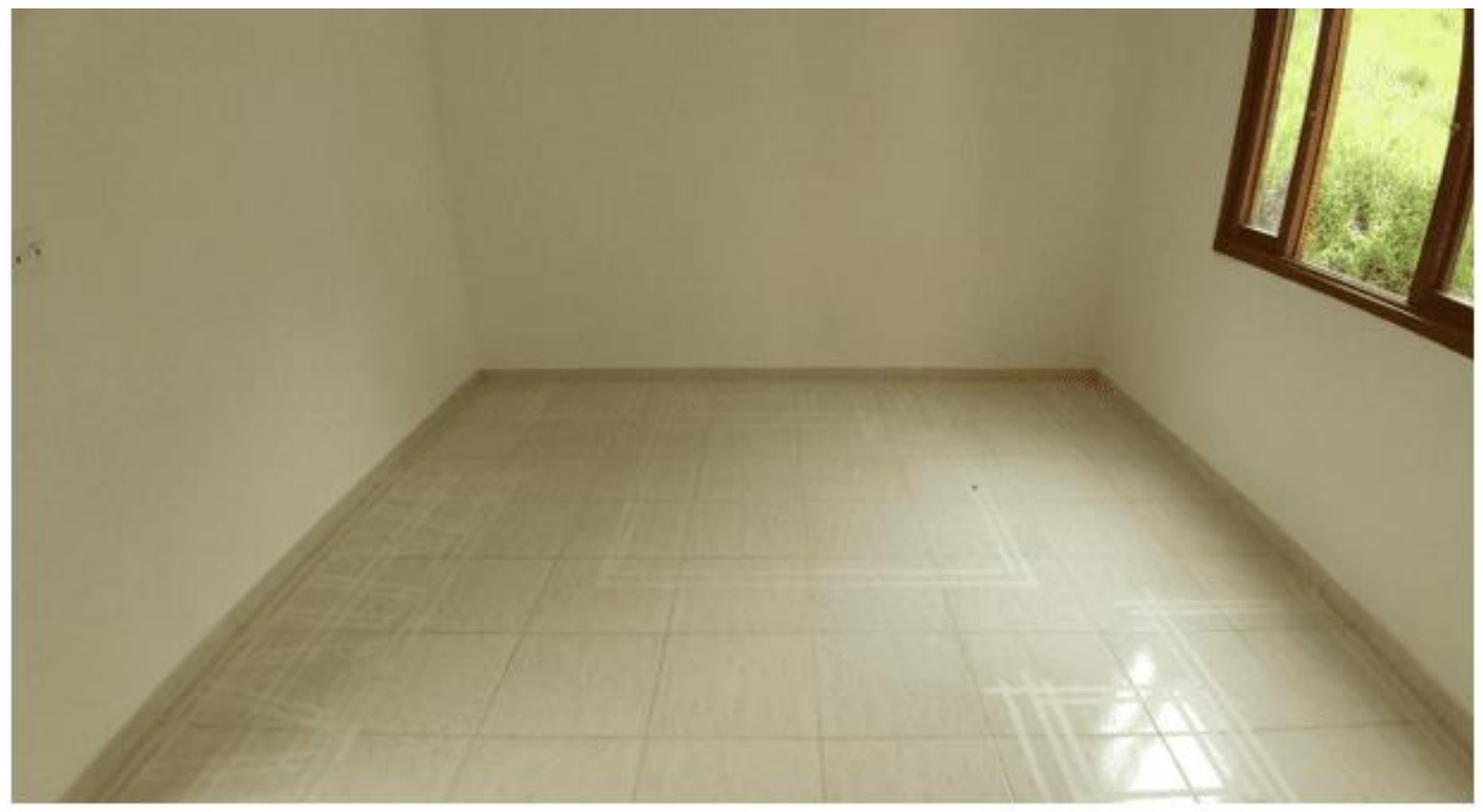

Fonte: Acervo do Laboratório Casa Sustentável (LCS), 2018.

O quarto eficiente possui abordagens diferentes para os meses de verão e de inverno. Para o verão, possui venezianas que promovem a saída de ar quente e a entrada de ar fresco na edificação, e beiral no telhado. Para o inverno, possui placas fotovoltaicas que promovem o aquecimento de ar. 
Além disso, assim como em toda a Casa, possui revestimentos que absorvem os sons e aquecem o ambiente, como a madeira, trazendo mais conforto acústico e térmico ao local.

Figura 10: Quarto eficiente visto externamente.

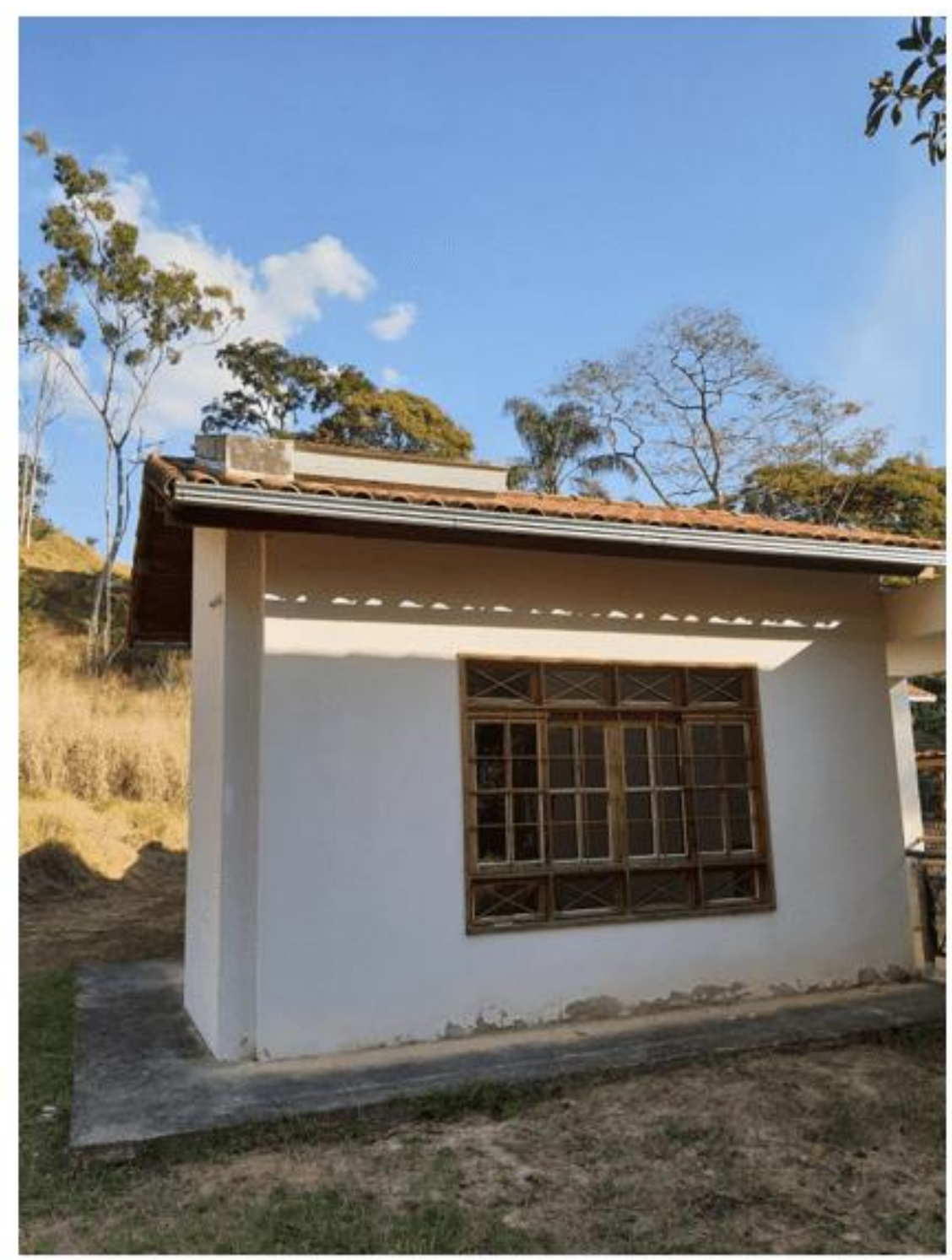

Fonte: Acervo do Laboratório Casa Sustentável (LCS), 2018.

$\mathrm{Na}$ sala de estar, há uma varanda-estufa orientada para a fachada Norte que, quando aberta, facilita a ventilação Norte-Sul predominante da cidade, em que as 
aberturas dos telhados conduzem a saída de ar quente, gerando resfriamento durante o verão.

Durante o inverno, as aberturas da varanda são fechadas e permitem a incidência solar no período da tarde, gerando o aquecimento do ambiente.

Figura 11: Sala de Estar e varanda-estufa.

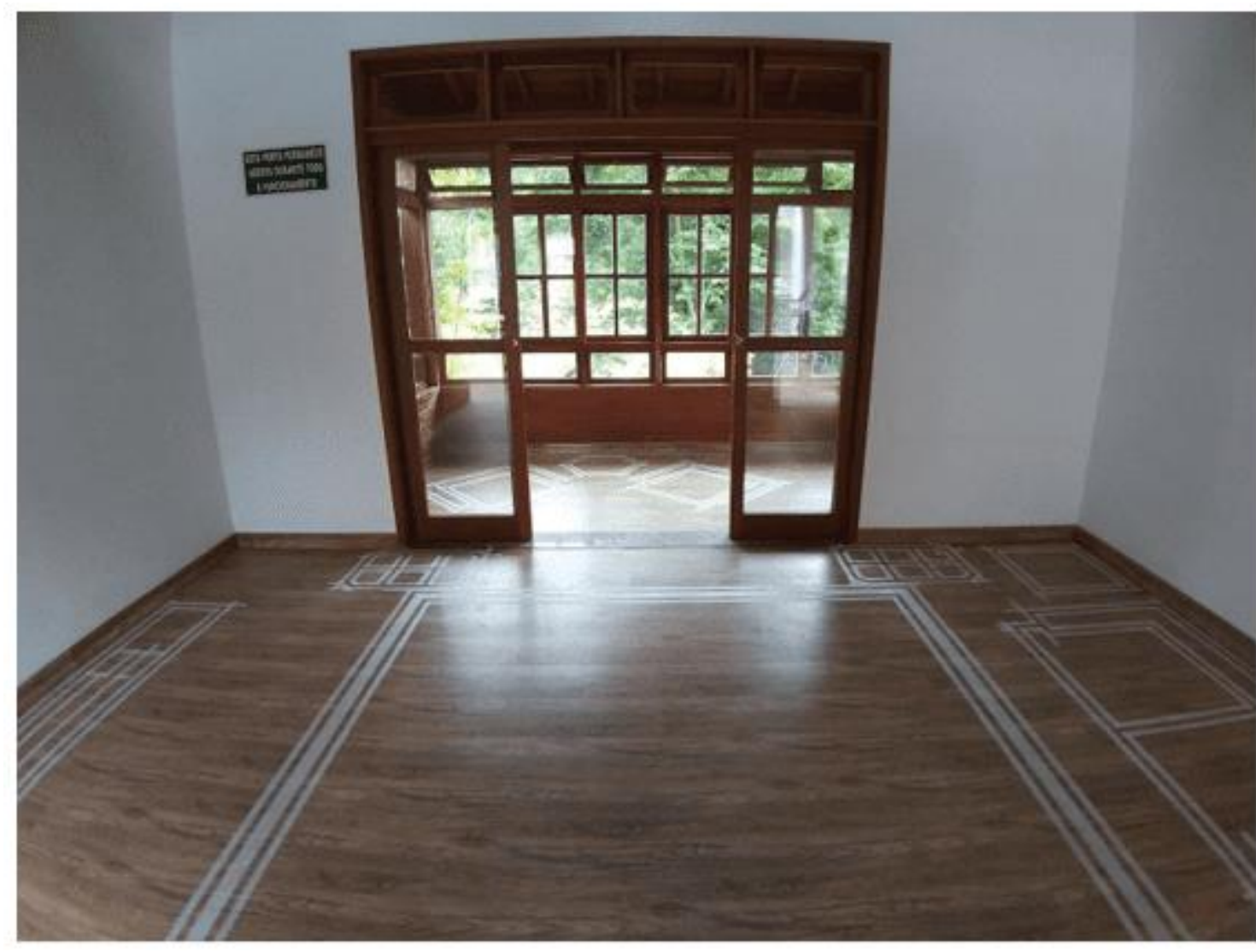

Fonte: Acervo do Laboratório Casa Sustentável (LCS), 2018.

No escritório, do ponto de vista térmico, além da ventilação cruzada pela janela superior, há a troca de ventilação por um duto embutido no solo, que capta ar em uma região do Jardim Botânico e o transmite - já resfriado pelo contato com o solo para o ambiente, através de ventiladores que forçam essa condução. No inverno, as aberturas superiores são fechadas e o mecanismo do duto no solo transfere o ar com temperatura mais amena para o escritório.

RC: 104796

Disponível em: https://www.nucleodoconhecimento.com.br/arquitetura/arquiteturabioclimatica 
Figura 12: Esquema projetual do duto de ventilação.

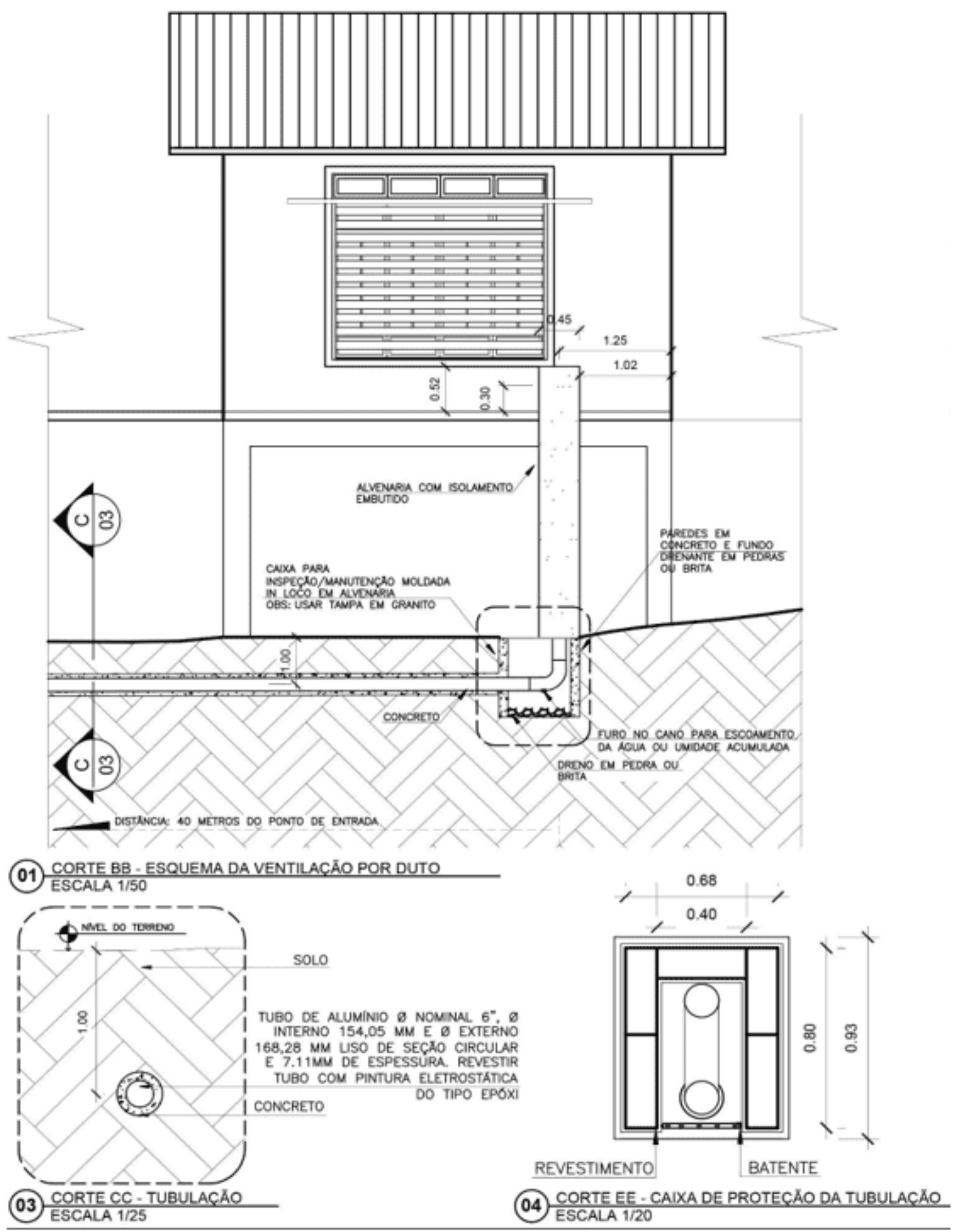

Fonte: Acervo do Laboratório Casa Sustentável (LCS), 2014.

RC: 104796

Disponível em: https://www.nucleodoconhecimento.com.br/arquitetura/arquiteturabioclimatica 
Para o conforto lumínico, houve uma ênfase na iluminação natural através da prateleira de luz, que consiste em uma técnica que promove tanto o sombreamento (impedindo a incidência direta de radiação) quanto a redistribuição de luz, que incide na prateleira branca, reflete no forro branco e se distribui pelo ambiente.

Além disso, há também o brise soleil que impede a radiação solar direta no ambiente, evitando ofuscamento no escritório.

Esse ambiente também conta com trilhos de luz com intensidade e temperatura ajustáveis, para que o usuário possa votar em quais condições se sente mais confortável, contribuindo para a pesquisa.

Figura 13: Trilho de iluminação didático e forro refletivo do escritório.

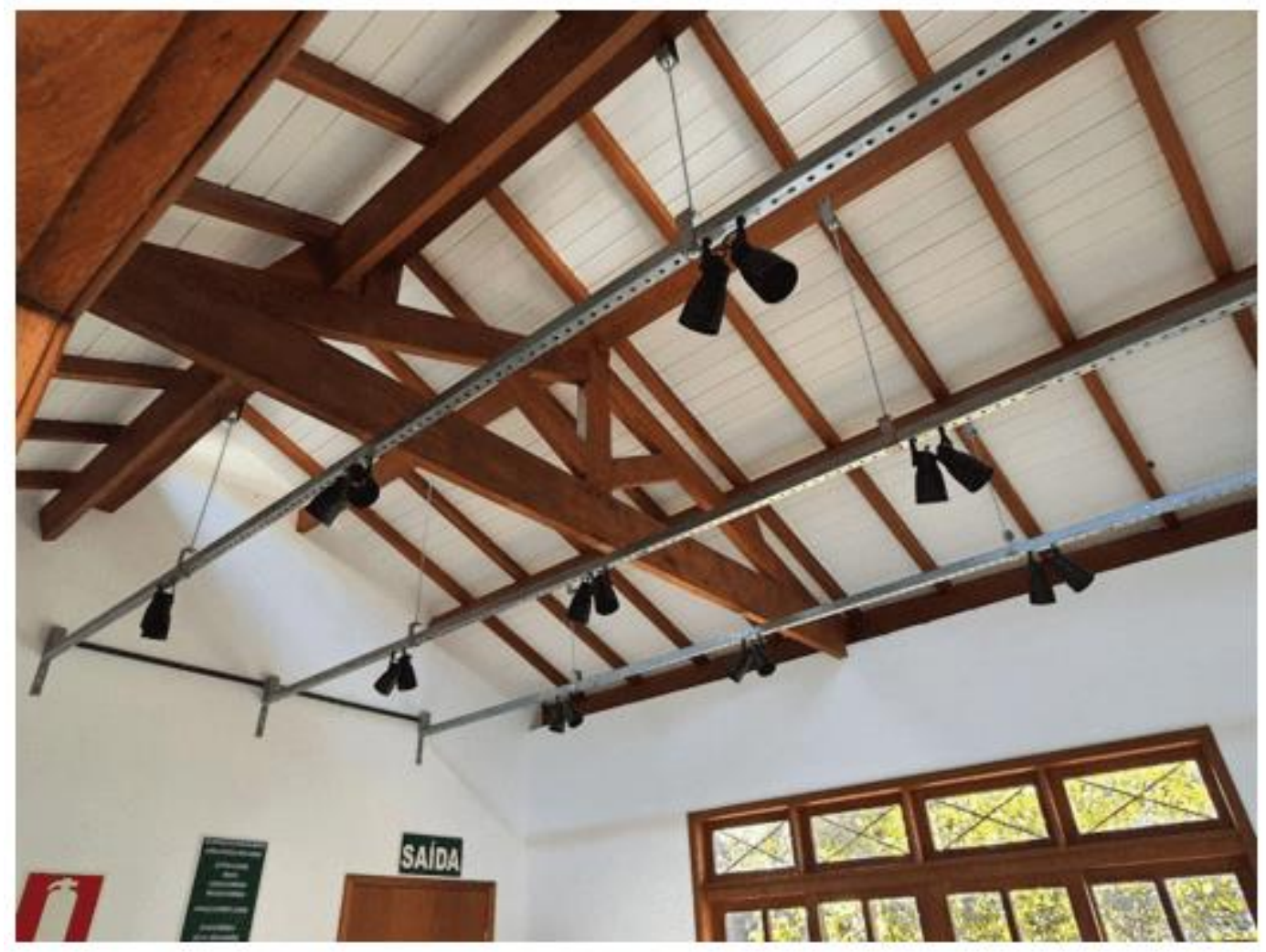

Fonte: Acervo do Laboratório Casa Sustentável (LCS), 2021.

A cozinha, por sua vez, possui laje vegetalizada que promove inércia térmica e captação de gás carbônico - além de substituir a área impermeabilizada do solo.

RC: 104796

Disponível em: https://www.nucleodoconhecimento.com.br/arquitetura/arquiteturabioclimatica 
Figura 14: Laje vegetalizada e placas de aquecimento solar da água, sobre teto da cozinha.

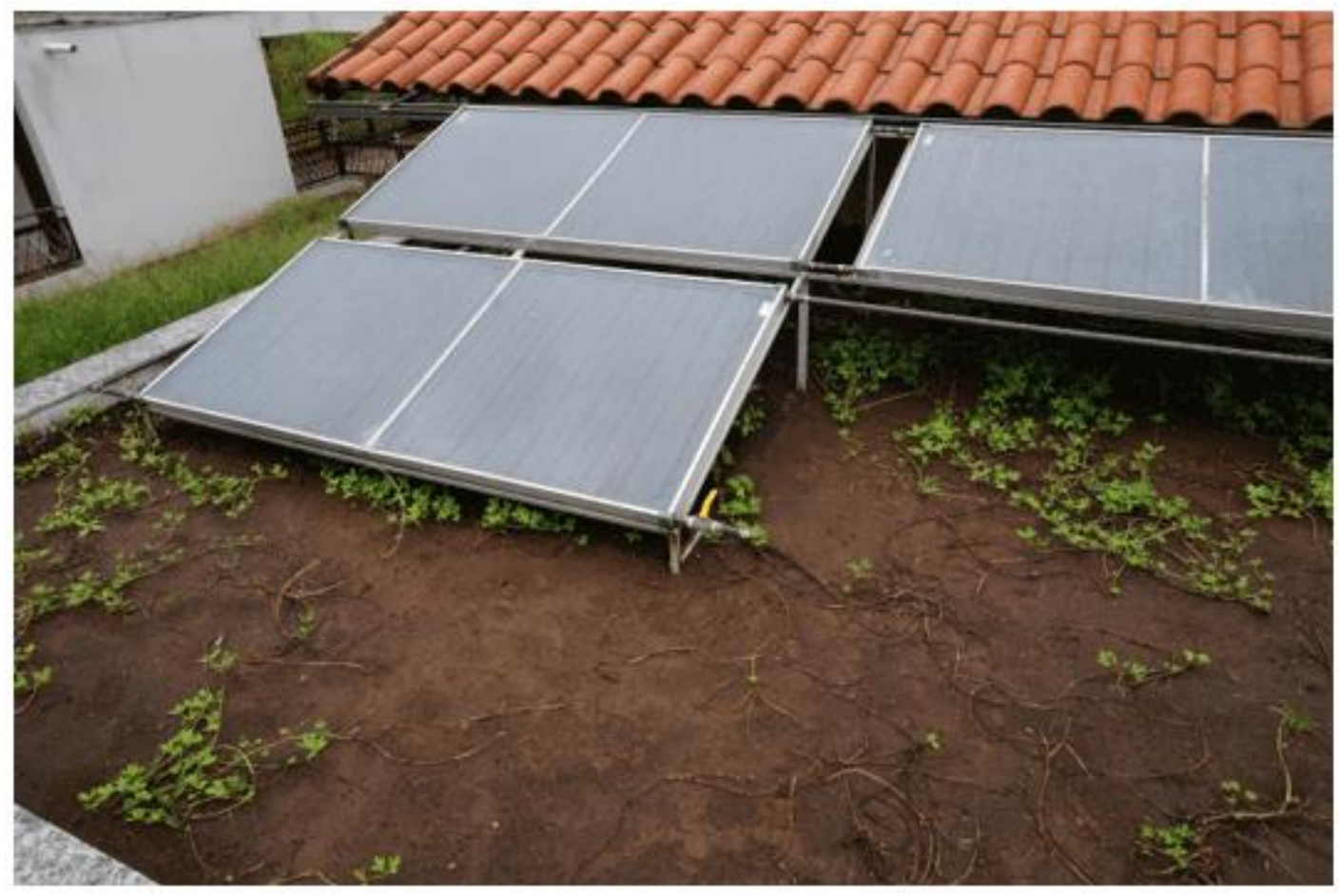

Fonte: Acervo do Laboratório Casa Sustentável (LCS), 2018.

Em fase de pré-execução, há a horta para culinária, que promove discussões amplas sobre sustentabilidade habitacional.

RC: 104796

Disponível em: https://www.nucleodoconhecimento.com.br/arquitetura/arquiteturabioclimatica 
Figura 15: Horta suspensa na cozinha (renderização projetual).

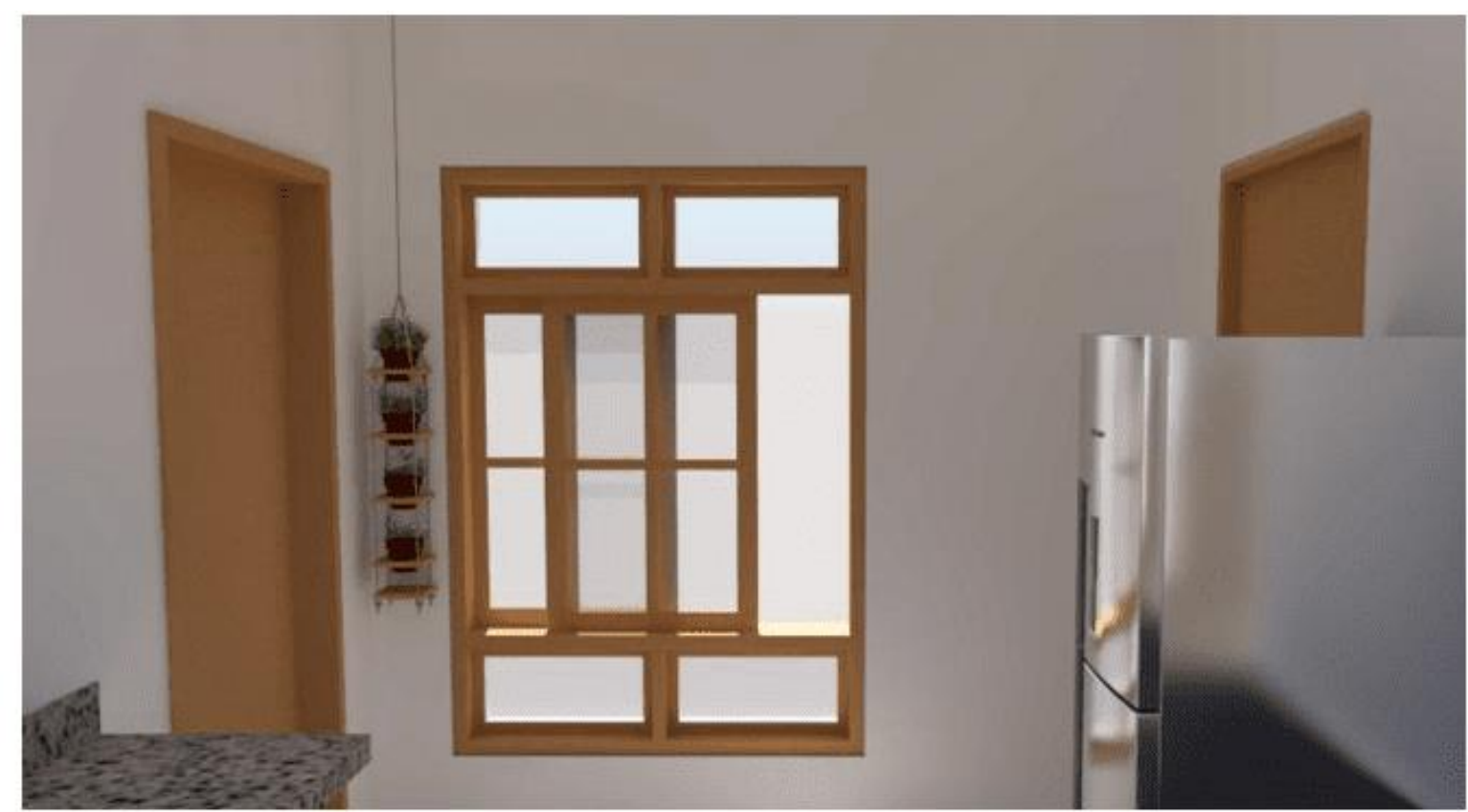

Fonte: Acervo do Laboratório Casa Sustentável (LCS), 2019.

O banheiro possui louças e equipamentos (vaso, pia e chuveiro) duplicados para que sejam comparados os modelos eficientes e ineficientes, demonstrando a importância do controle de fluxo de água. Além disso, há aquecimento da água pelas placas fotovoltaicas mostradas anteriormente.

O local possui duas caixas d'água, uma da rede pública e outra da captação de água da chuva - que irriga as áreas verdes e abastece o vaso sanitário -, e um boiler - que faz o aquecimento de água -, sendo todos visíveis como forma de ensino sobre o funcionamento técnico dessas estratégias para os visitantes. 
Figura 16: Banheiro acessível.

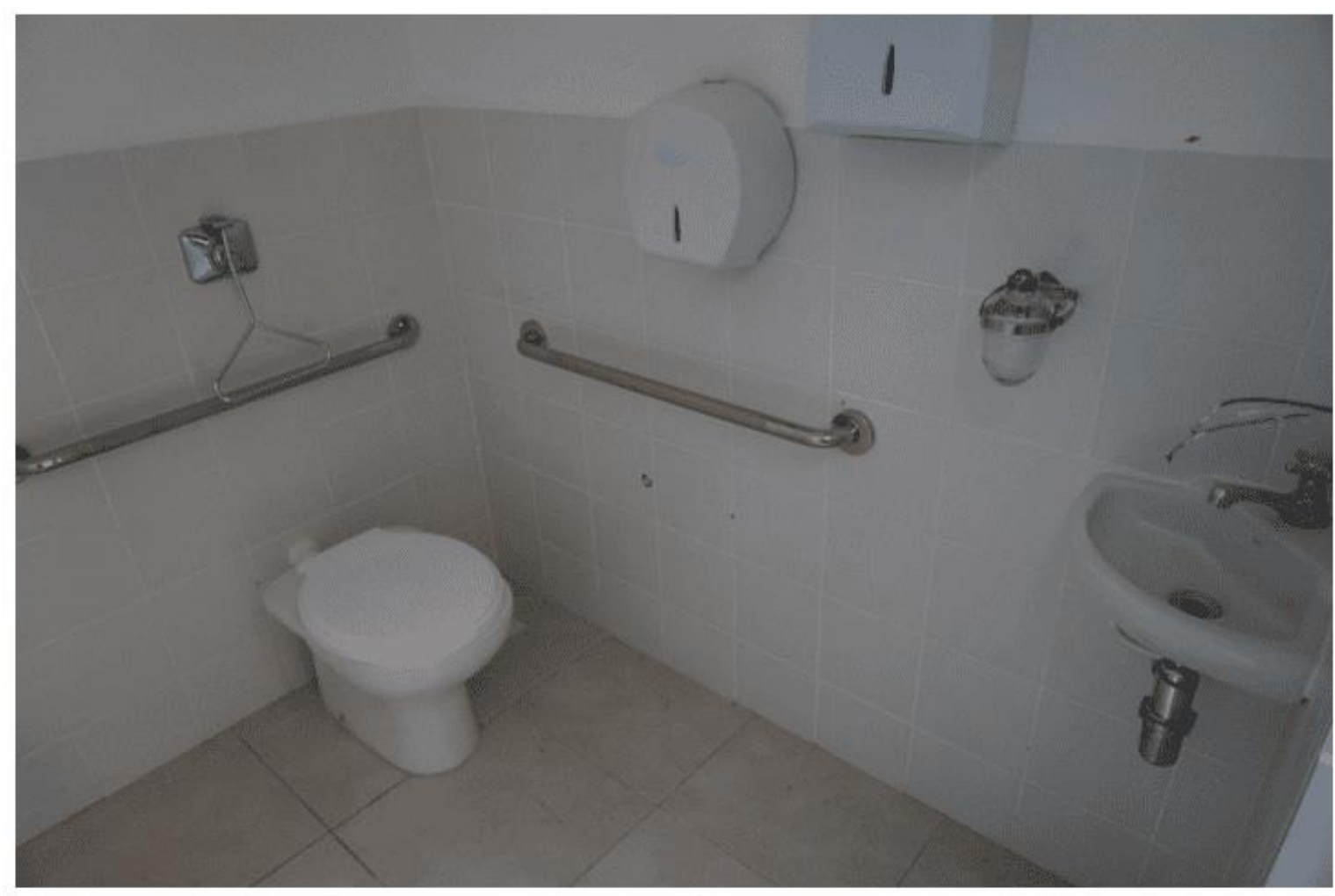

Fonte: Acervo do Laboratório Casa Sustentável (LCS), 2018. 
Figura 17: Caixas d'água e boiler expostos para fins didáticos.

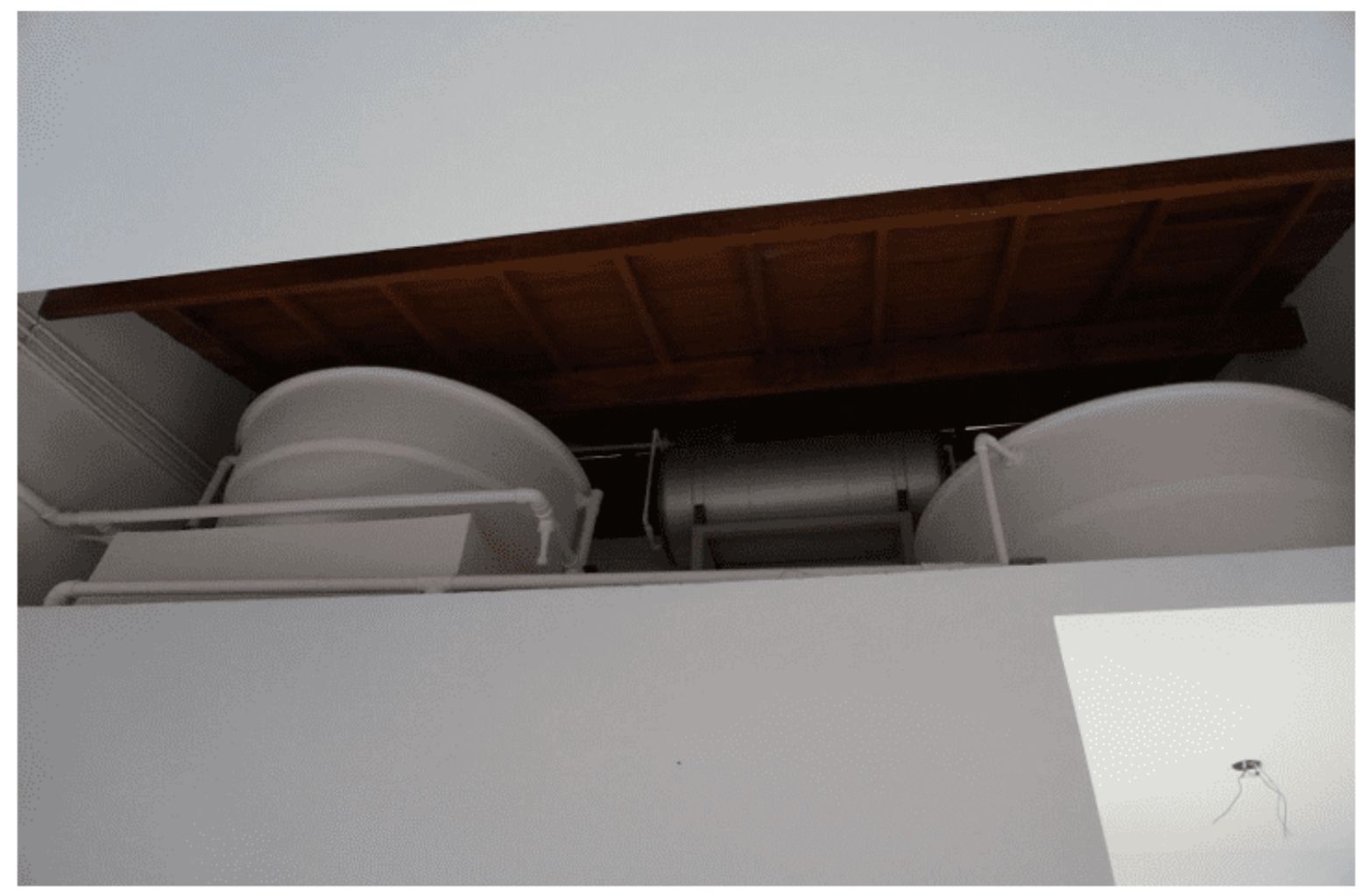

Fonte: Acervo do Laboratório Casa Sustentável (LCS), 2018.

Finalizando o percurso, há uma rampa que protege a casa do sol poente e promove o contato da Casa com a área externa abundante em natureza, explorando o conceito de biofilia. 
Figura 18: Rampa que dá acesso externo aos ambientes.

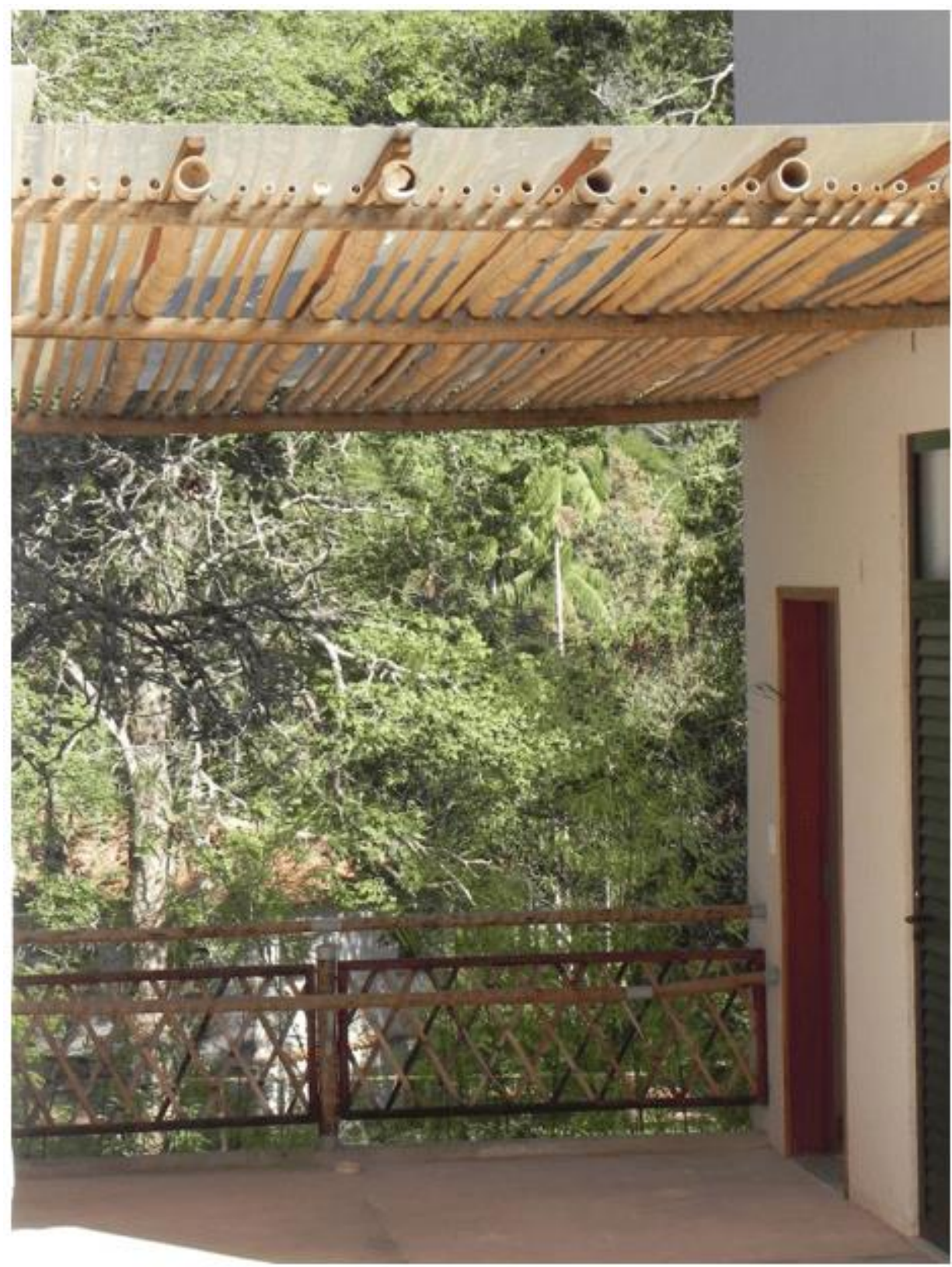

Fonte: Acervo do Laboratório Casa Sustentável (LCS), 2018.

Por fim, há o pátio interno, que está em fase de pré-execução, com paisagismo baseado no percurso das águas das chuvas, que se estocam em um pequeno lago que se aproveita de uma ruína já existente no terreno. Posteriormente, a água é conduzida naturalmente para a cisterna que bombeia novamente para a caixa d'água superior.

RC: 104796

Disponível em: https://www.nucleodoconhecimento.com.br/arquitetura/arquiteturabioclimatica 
Além disso, as espécies botânicas escolhidas são nativas da região e adequadas para os serviços ecossistêmicos desejados.

As figuras a seguir mostram algumas imagens projetuais desse ambiente.

Figura 19: Projeto do deck do pátio interno.

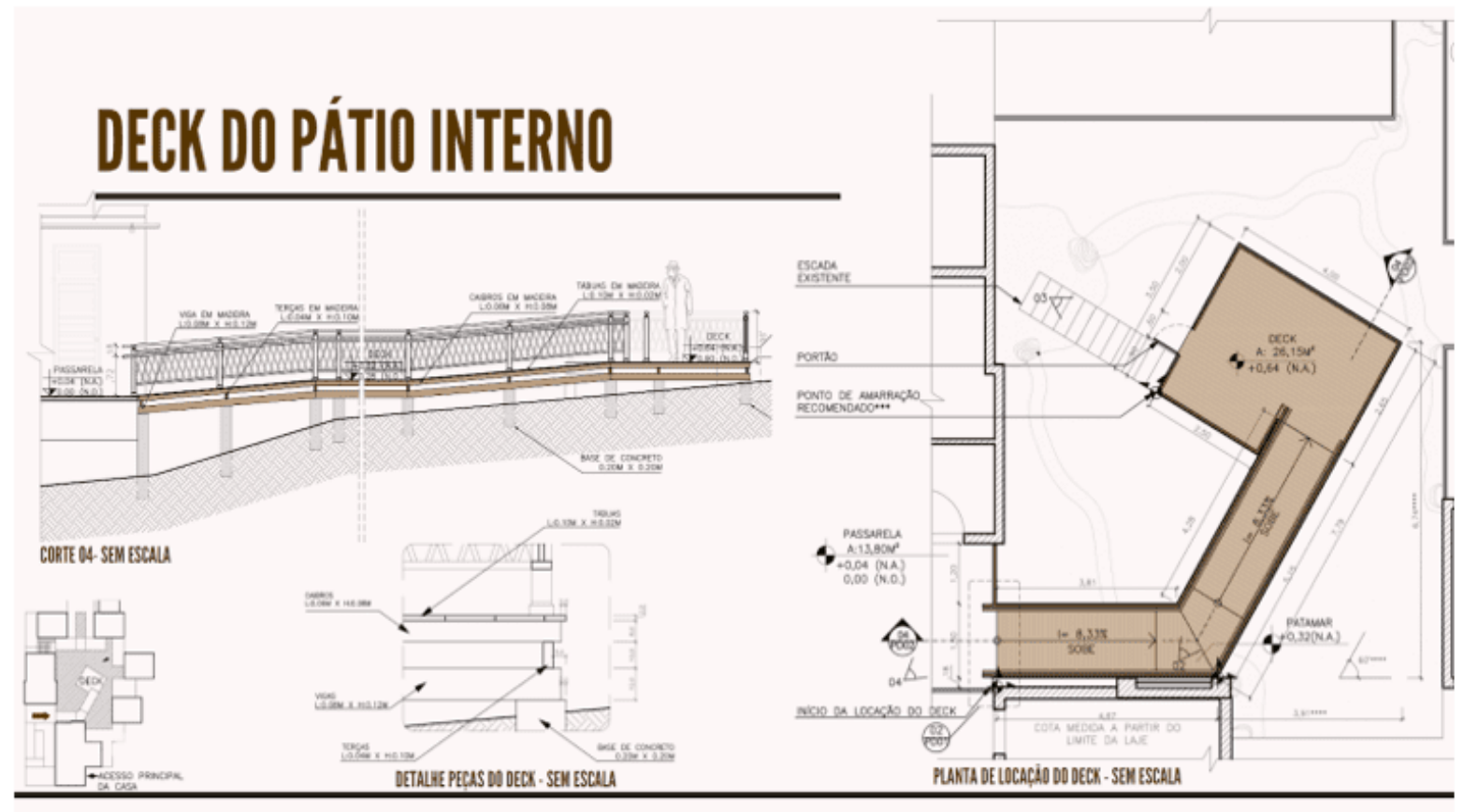

Fonte: Acervo do Laboratório Casa Sustentável (LCS), 2018.

RC: 104796

Disponível em: https://www.nucleodoconhecimento.com.br/arquitetura/arquiteturabioclimatica 
Figura 20: Projeto de paisagismo do pátio interno.
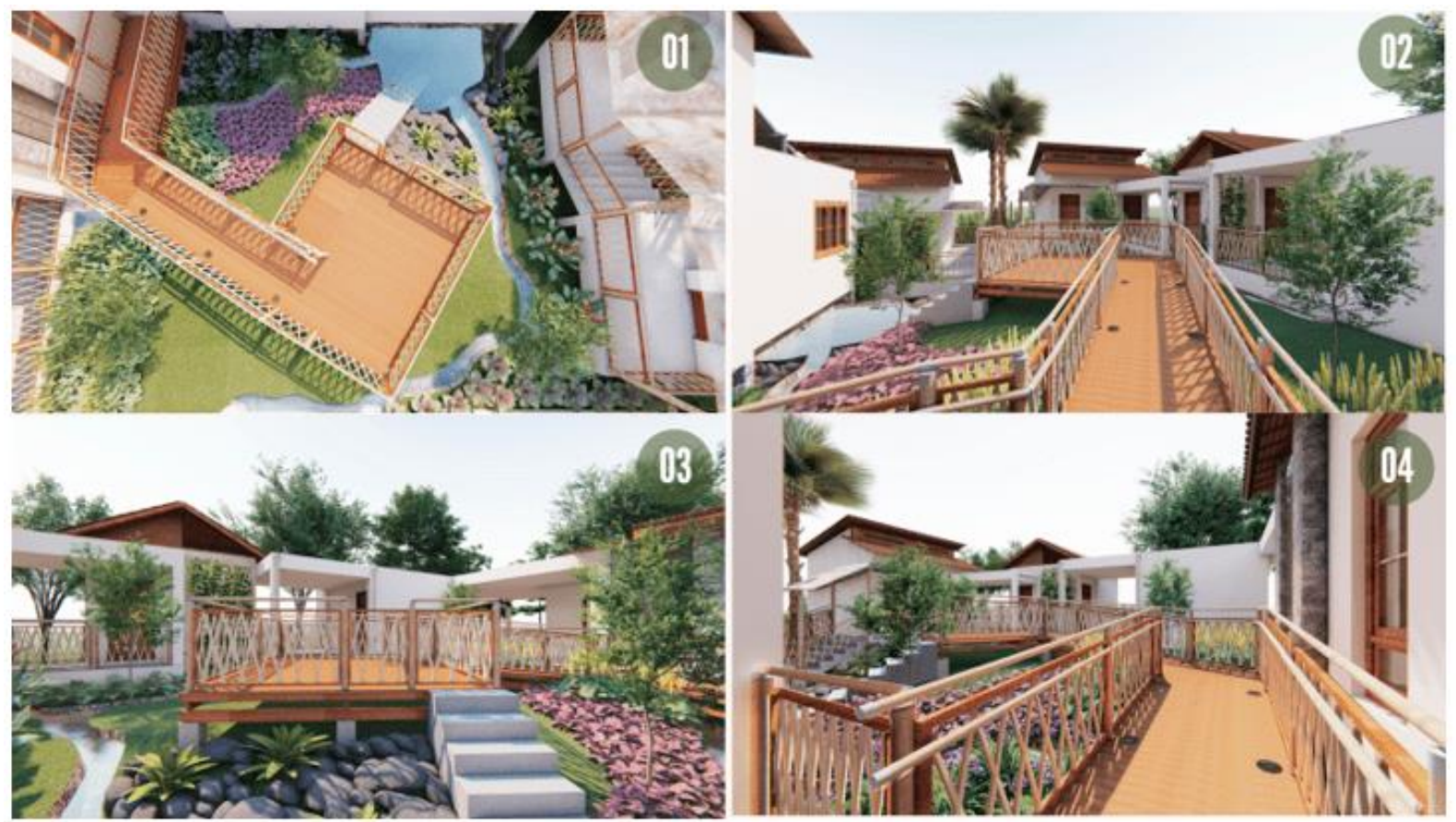

Fonte: Acervo do Laboratório Casa Sustentável (LCS), 2018.

Figura 21: Projeto de cursos d'água do pátio interno.

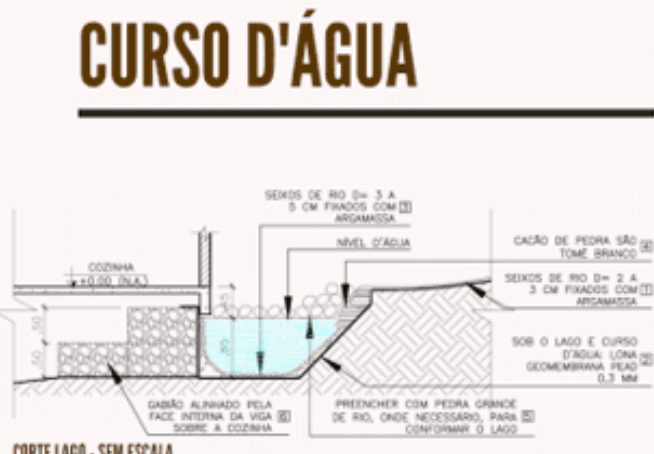

CORIE LAGO - SEM ESEALA

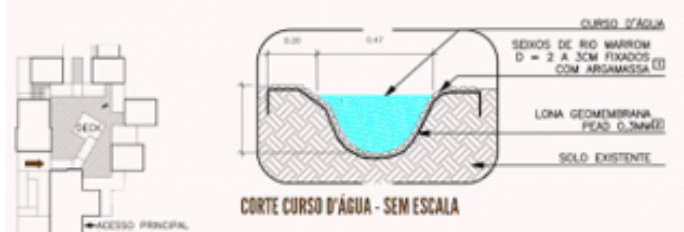

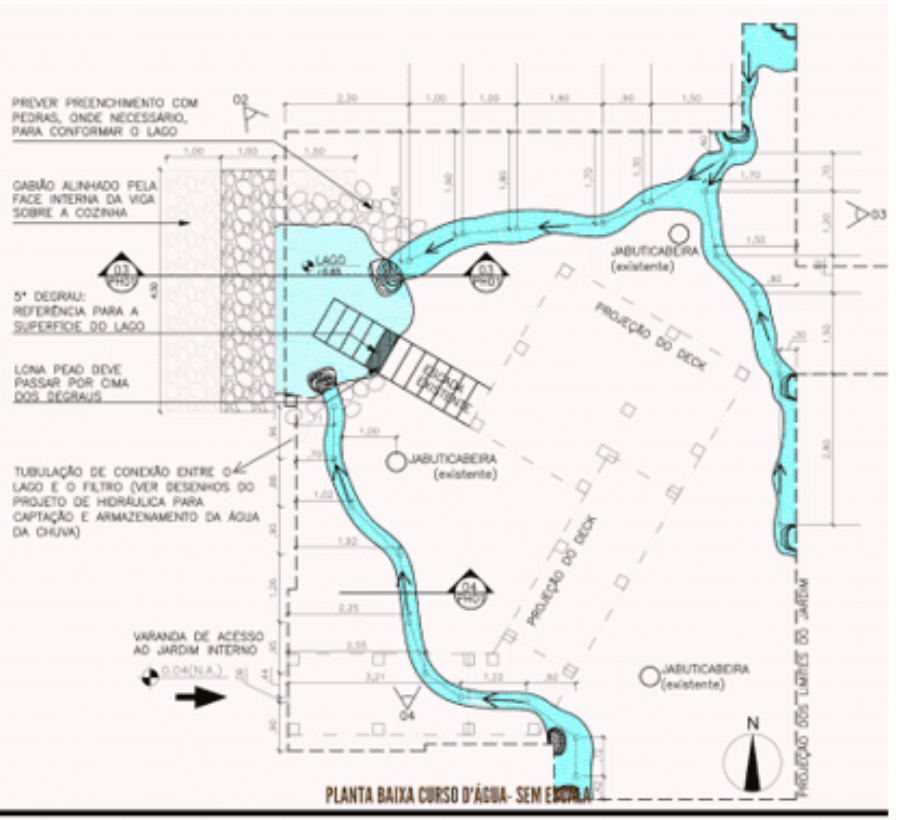

Fonte: Acervo do Laboratório Casa Sustentável (LCS), 2018.

RC: 104796

Disponível em: https://www.nucleodoconhecimento.com.br/arquitetura/arquiteturabioclimatica 
Todo o trajeto é acessível a pessoas com deficiência motora e em breve também será a pessoas com outros tipos de deficiência.

O percurso conta, também, com equipamentos de medição de temperatura, iluminação e umidade que, através de testes com diferentes formas de uso, indicam dados que revelam os níveis de conforto ambiental, onde os visitantes poderão demonstrar suas condições de conforto no ambiente. A partir das respostas levando em consideração dados como temperatura, umidade do ar, vestimentas utilizadas, ânimo, metabolismo de cada indivíduo, entre outros fatores - será possível finalizar a pesquisa quali-quantitativa dos ambientes e mensurar os níveis de conforto térmico e luminoso de cada cômodo da casa.

Figura 22: Equipamento de medição de dados de conforto ambiental.

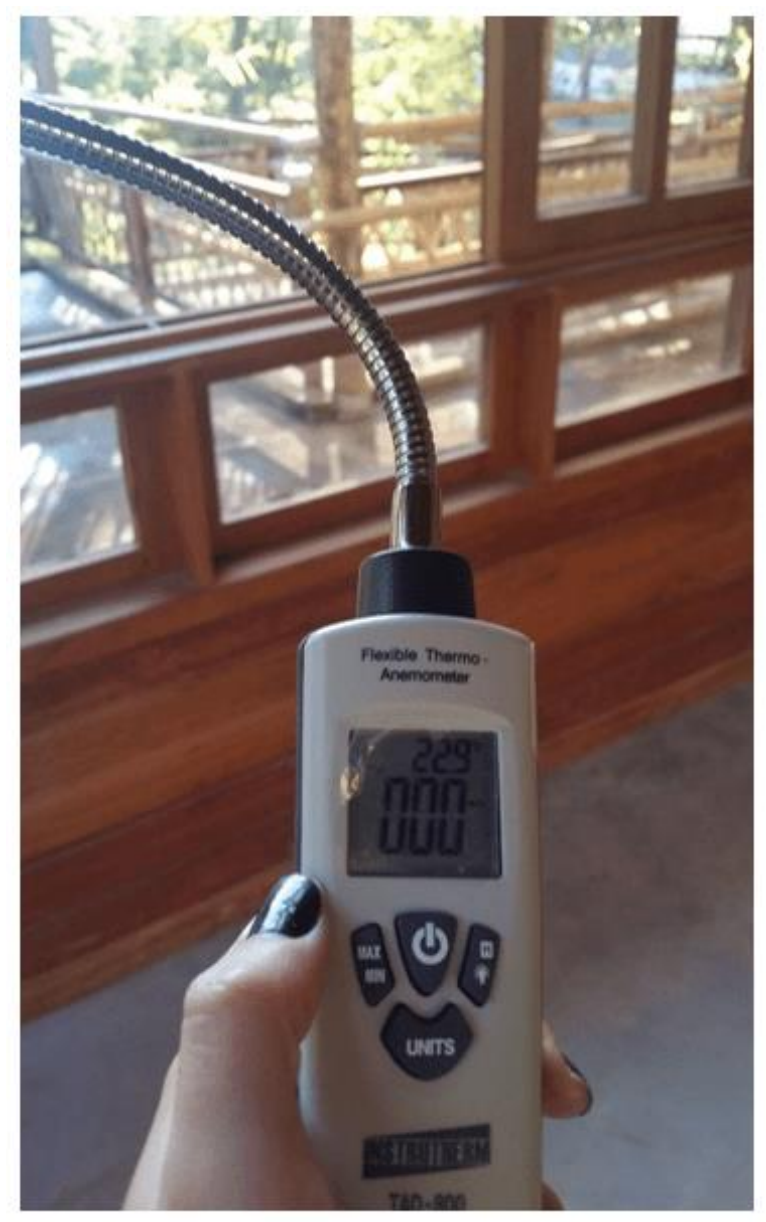

Fonte: Acervo do Laboratório Casa Sustentável (LCS), 2018.

RC: 104796

Disponível em: https://www.nucleodoconhecimento.com.br/arquitetura/arquiteturabioclimatica 


\section{EXPERIÊNCIA COMO PROJETISTAS E MONITORAS DA CASA SUSTENTÁVEL}

A experiência como projetistas e monitoras da casa sustentável enriqueceu o repertório de produção das autoras, trazendo experiências diferenciadas, como a oportunidade de passar por todas as etapas de um projeto, desde a pesquisa de concepção até sua execução e adaptação com o público.

Além disso, é notável a expansão de conhecimento teórico sobre arquitetura, conforto ambiental, bioclimatismo, sustentabilidade, e sobre suas aplicações na prática.

O trabalho das autoras na construção de material didático com linguagem acessível para os visitantes, e enquanto guias de visitação na Casa, proporcionou maior sensibilidade e humanização ao projetar - aspectos imprescindíveis a todo profissional de arquitetura e urbanismo.

Devido a todos esses fatores, tais aprendizados tornam nítida a diferença entre os projetos acadêmicos e profissionais anteriores e posteriores à participação no Laboratório.

\section{CONSIDERAÇÕES FINAIS}

Como produto do trabalho, registrou-se uma apresentação didática, a partir dos dados técnicos e práticos do projeto, de maneira que fosse possível perceber o papel de educação ambiental que o Laboratório Casa Sustentável possui, tanto para a área acadêmica quanto para a população de forma geral.

A pesquisa demonstra a viabilidade de aplicação da maioria das estratégias presentes na Casa Sustentável, por parte dos visitantes, em suas próprias moradias, visto que são, de forma geral, acessíveis e eficientes. 
Também foi possível perceber que a construção se aproveita das características naturais do local em que está inserida, como terreno, ventilação, posição natural do sol, plantas nativas, materiais locais, entre outros. Tais estratégias são essenciais no exercício da arquitetura e do urbanismo, cumprindo essas expectativas de ensino da profissão.

Portanto, retomando a questão norteadora: de que forma o Laboratório Casa Sustentável atua a fim de estabelecer diálogo e orientação ambiental às comunidades local e acadêmica? Conclui-se que, como resultado, o trabalho demonstrou que o LCS atua de forma prática na orientação ambiental da população e da comunidade acadêmica, demonstrando através do trajeto guiado técnicas arquitetônicas acessíveis e replicáveis.

Por fim, tornou-se notável a potencialidade de projetos acadêmicos que envolvem a cidade e a população, incluindo diálogo constante com os visitantes e gerando conhecimentos práticos para eles, ao passo que enriquece a experiência prática de alunos, bolsistas e pesquisadores.

\section{REFERÊNCIAS}

ASSOCIAÇÃO BRASILEIRA DE NORMAS TÉCNICAS. NBR 15220: Desempenho térmico de edificações Parte 3: Zoneamento bioclimático brasileiro e diretrizes construtivas para habitações unifamiliares de interesse social. ABNT, Rio de Janeiro, 2004.

ESTAÇÃO CLIMATOLÓGICA PRINCIPAL DE JUIZ DE FORA. Juiz de Fora, 2012.

PROJETEEE. Estratégias Bioclimáticas. Disponível em: >http://www.mme.gov.br/projeteee/estrategias-bioclimaticas/?cidade=MG++Juiz+de+Fora\&id_cidade=bra_mg_juiz.de.fora.836920_inmet<. Acesso em: 25 de set. de 2021.

HALLYDAY, Sandy. Sustainable constructions. Netherlands: Elsevier, 2008. 
RHEINGANTZ, Paulo Afonso; AZEVEDO, Giselle Arteiro; BRASILEIRO, Alice; ALCANTARA, Denise de; QUEIROZ, Mônica. Observando a qualidade do lugar: procedimentos para a avaliaçã o pós-ocupação. Rio de Janeiro: PROARQ/FAU-UFRJ, 2009. Disponível em: <http://prolugar.fau.ufrj.br/wp-content/uploads/2020/09/Observando-a-Qualid-doLugar.pdf>. Acesso em: 25 de set. de 2021.

SANMIGUEL, Sandra. Un Vitruvio Ecológico. Spain: Gustavo Gili, 2007.

SCHLEIFER, S. K. (ed. coord.). Green House pour une habitation éco-logique. France: Maomao publications, 2010.

ZAMBRANO, Letícia Maria de Araújo. A Integração Dos Princípios da Sustentabilidade ao Projeto de Arquitetura. Tese de Doutorado em Arquitetura, Universidade Federal do Rio De Janeiro, Rio de Janeiro: PROARQ/FAU-UFRJ, 2008.

ZAMBRANO, Letícia Maria de Araújo et al. Laboratório Casa Sustentável: um ambiente de ensino, pesquisa e extensão em arquitetura em Juiz de Fora - MG. XIII Encontro Nacional e IX Encontro Latino-americano de Conforto no Ambiente Construído. Brasil, 2008.

ZAMBRANO, Letícia Maria de Araújo; MARQUES, Aline Calazans. Sustentabilidade e Habitação: projetos de extensão que promovem inovação. 2020. Disponível em: $<$ https://www.youtube.com/watch?v=Y8Q6ZGhEWyo\&list=LL\&index=24\&t=4647s>. Acesso em: 24 de set. de 2021.

Enviado: Novembro, 2021.

Aprovado: Janeiro, 2022. 